\title{
Comparative Analysis Of Oil Company's Corporate Social Responsibility Operating in Different Environments (Nigeria and USA)
}

\author{
I.B. Wulo ${ }^{1}$, Y. Mohammed ${ }^{2}$, Y. Djauro ${ }^{3}$, D.D Mohammed ${ }^{4}$, U.A Usman ${ }^{5}$, \\ H. M. Sadiq ${ }^{6}$, M. Kodomi ${ }^{7}$, A.K. Gazali ${ }^{8}$, H. I. Kamale ${ }^{9}$, Y. Ibrahim ${ }^{10}$ \\ Department of Geology, Faculty of Science, University of Maiduguri, Nigeria
}

\begin{abstract}
This research is an attempt at finding the institutional trajectories of Royal Dutch Shell operations concerning the question of Corporate Social Responsibility/Social Investment (CSR/SI) strategies in two different environments i.e. The United States and Nigeria. In the quest to ascertain these facts and variables, the question of adequacy of this responsibility and the policy framework of Royal Dutch Shell has become a subject of concern being that issues of corporate strategies towards different states and communities around the globe has raised questions of disparate arrangements, approaches and attitudes.A perusal of various literature and reports, including the Social Investment Disclosure in the sustainability report of the Royal Dutch Shell (2012), as well as economic indices and demographic data suggest how the question of CSR is a field amass with facts and figures about how differently global conglomerates approach their corporate responsibility toward host communities. The subject of CSR/SI strategies as contained in the analysis of the sustainability report of the Royal Dutch Shell (2012) states that in Nigeria. Yet, the Key Performance Indicators (KPI) reveals some level of inadequacy of the company's Social Investment (SI) programmes in Nigeria as compared to the United State.), and the "Lack of Goodwill" Indicators designed by IPIECA (2008), bring to the fore the demographic and socio-economic indices of the two environments, which give an insight into issues that include ethical considerations and limitations. Most of the thematic issues show that the Royal Dutch Shell has in place diverse social and voluntary investments programs.
\end{abstract}

Keywards: Environment, Corporate Social Responsibility, Niger-Delta and Oil \& gas

\section{Introduction}

Corporate Social Responsibility has no single universal acceptable definition rather it has series of definitions that came into being over time. The concept of CSR was first introduced by Howard R. Bowen (1953) where he made mention that the moral duty of managers obligate them to reflect on the social impact of their activities when taking decision, and stresses that any corporation that fail or refuses to do that should be considered as illegitimate (Stainer 2006). According to Bowen, legality transmit to opinion that an action of a company is right or anticipated, within a structure of customs based on social values, opinions and expectations (Amadi 2013). Some of the first steps set in the effort at conceptualising CSR were the work of Bowen where he said, "The obligation of business men to follow those policies, to make those decisions, or actually to follow those lines of action which are desirable in terms of the objectives and values of our society". The significance of this statement is those business organisations are expected or supposed to spread their tasks to values other than turnover and other benefits only. Davis (1960) as cited in Carroll (1999) opined that CSR is a "business men's decisions or actions taken at least partially beyond the firms direct economic or technical interest." However, the corporate organisation may in feature benefit from its social responsibility perspective. Backman (1975) as cited in Gonzalez-Padron (2008) also backs this opinion when he mentioned CSR as "key objectives and motives that should be given weight by businesses in addition to those dealing with economic performance." Backman continued to list motivations such as minority group employment (which can be understood to refer or comprises of indigenous people), greater involvement in packages that will develop the community and any other effort that will better and improve the quality life of people in the area of operation.

This research intends to investigate if Royal Dutch Shell Petroleum Company is operating different forms of Corporate Social Responsibility (CSR) strategy, and the satisfactoriness of the approach in obtaining social licence to operate in Niger Delta of Nigeria. Hence, the objective of this research work is bounded with Shell's corporate social responsibility policies in Nigeria and how well are those policies and their implementation compared to the one they carry out in United States.

The research also intends to evaluate the adequacy of corporate social responsibility policies of Royal Dutch Shell Petroleum Company ensures in place or planning to ensure. Specific objectives are to; Compare and contrast the corporate social responsibility strategies of Shell in Nigeria's Niger Delta region with that of the USA, to find out how corporate social responsibility strategies been employed by Royal Dutch Shell company in 
Nigeria as against what is operational in USA and to evaluate the adequacy of the strategies in corporate social responsibility of Shell Company in the Niger Delta region of Nigeria.

\section{The Oil and Gas Environments in Nigeria and USA}

The country (Nigeria) is located in west of Africa, sharing borders with Cameroun, Chad, Niger, Benin republic and Atlantic Ocean. As reported by the Nigerian National Petroleum Company (NNPC), oil exploration started since 1937 while first oil production kicked up in 1956 by Shell petroleum development company (SPDC) in an oil field called Oloibiri in Bayelsa state in Eastern part of Niger Delta. Nigeria and Shell have being partners for a long time, hence the interest in looking at its CSR/SI policies in the country.

According to (NNPC) oil and gas reserves estimate stands at 28.5 billion barrels of oil while natural gas and associated gas reserves are 165 trillion and 75.4 trillion scf respectively. Nigeria's crude production rate is estimated to be 2.5 million bpd while that of Natural gas is 2,400.40 billion cubic feet. Base on the data, Nigeria is said to be the leading producer of oil and the sixth principal in the world, making crude oil the major source of the countries income (IPIECA, 2008). All this data are in close proximity to that of United States.

Estimate shows that Nigeria is the largest producer of oil in Africa. The oil and gas industry is the strength and centre of the Nigerian economic (Crude Oil) accounting for $98 \%$ of its export earnings and $75 \%$ of its Federal Government revenue (IMF data as cited in the EIA report of 2012). Therefore, from the above mentioned, it is not an overstatement to mention that the performance of the oil industry in Nigeria (Good or Bad) has an influence on the country and global economy. Figure: 1 is the map of the Niger Delta showing oil and gas wells. According to Ikelegbe (2005), the Nigerian government has for decades neglected the social welfare of the people living in the oil producing regions of the country, resulting in conflicts, poverty and crime. Incessant demand for social and infrastructural development, environment concerns, equity, justice, fairness has resulted to unhealthy act such as kidnapping of foreign oil workers, destruction of oil pipe lines and fighting government security forces. The people of the region have accused the government for their abject poverty, environmental pollution, degradation, depletion of their natural environment which is hitherto beneficial for life and economic activities. This is in addition to poor water quality bring about by the activities of oil exploration (Ukiwo 2009). With more than 32 million people, two thirds under the age of 30 and $43 \%$ surviving under poverty line, the region represents one of the world's leading development challenges (NDPI Annual report 2013: 7).

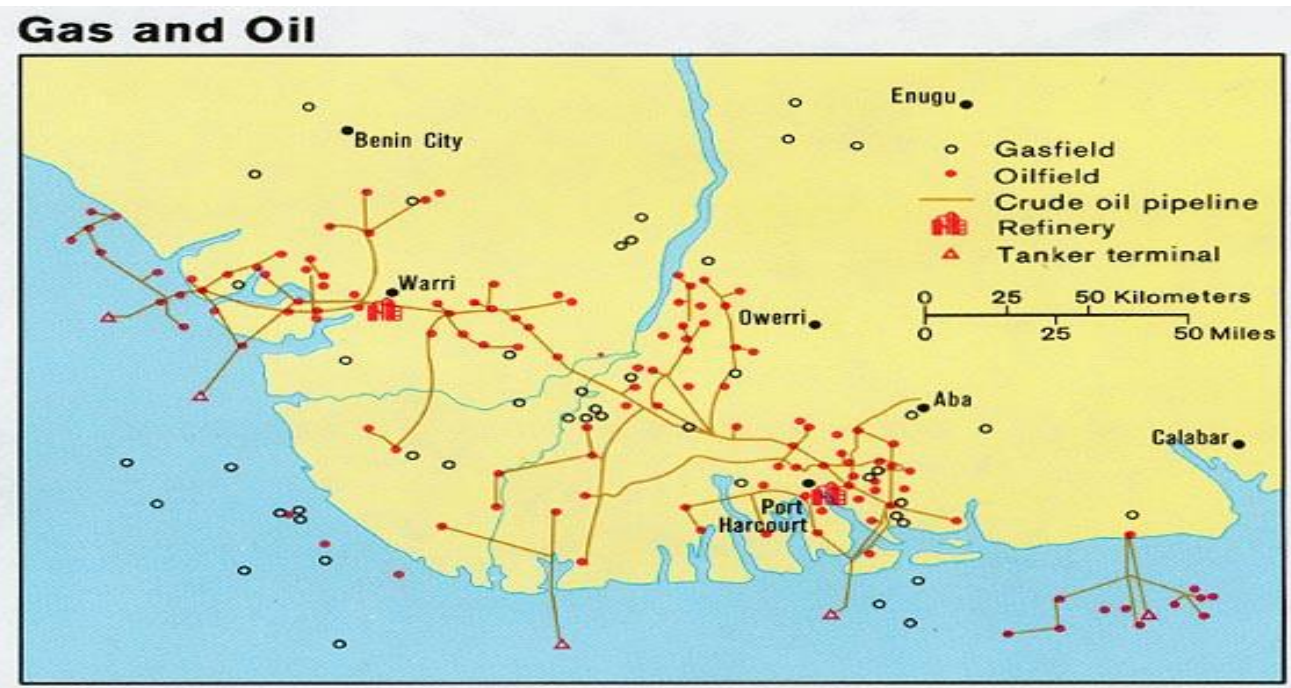

Figure: 1 Showing oil and gas fields in Niger Delta Area of Nigeria

Royal Dutch Shell is one of the foremost America's producers of oil and gas. They have large petrochemicals investment in the country. There activities in the deep water Gulf of Mexico alone are amounting to billions of dollars. There exploration activities started in 1912 and build refinery in Orlean, open Louisiana in 1916 and later in Wood River, Illinois in 1918. Acquired California oil field Ltd in 1913 (Plaza and Deisler 2014). Figure 2 is the map of US showing oil and Natural gas production areas in the United State. 


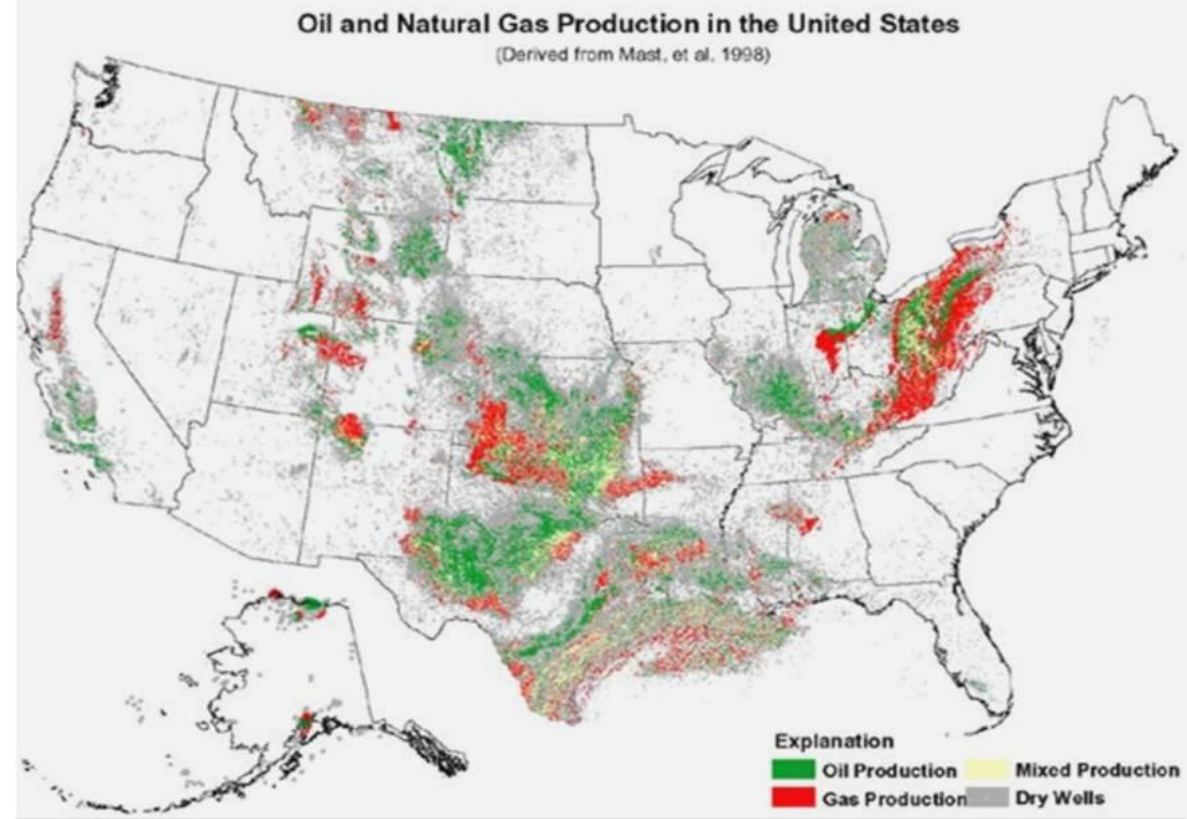

Figure: 2 Oil and natural gas areas in the United States.

Source: (TEEIC2011).

\section{Research Methodology}

This research work was carried out based on existing literature (secondary data), collected from a variety of sources through a sequence of consistent and systematic techniques. The methodological frame work of this research work is going to be an inferential reasoning one, for the simple fact that the data was collected from secondary source, using the case study approach. It is therefore a fact-finding and constructive research work, which intends to analyse the assumptions and theory of corporate social responsibility and possession of social licence to operate in two different environments by Shell Company, based on the company's social policy.

The framework for the collection and analysis of the data for this work is based on the importance relating to a range and scope of the research. Principally, qualitative data are collected for this research work from secondary sources. These sources include, Transparency International (TI) and Corruption Perception Index (2012), Royal Dutch Shell sustainability report (2012), World Bank Ease of Doing Business Index (2013), International Financial Corporation (IFC), United Nation Development Program, Human Development Indicator (HDI ) (2013), Demographic data, data from the CIA Fact Book (2013), Energy Information Administration of the US (EIA), International Petroleum Industry Environmental Conservation Association (IPIECA) and range of books and articles which are all duly acknowledged and referenced. Journals used are peer reviewed; organised government publications and internet material were used. Based on these sources, the information was used to compare the two countries. This process was carried out in three different stages:

Stage One: Economic and demographic data of USA/Nigeria.

Stage two: Content analysis of Royal Dutch Shell's sustainability report.

Stage Three: Adequacy of Social Investments (SI) of Royal Dutch Shell was analysed using the "lacks of good will social performance indicators" developed by IPIECA (2008).

In analysing the research work, key social performance indicator developed by IPIECA (2008) known as Lack of Goodwill Indicators was used in carrying out a comparative and content analysis. In addition to that, the "Lacks of Goodwill Social Performance Indicators" developed by IPIECA (2008) were assessed based on information and data available from secondary sources.

\section{Demographic Data}

\section{Results And Discussion}

\section{Land Mass, Population size and Gross Domestic Product (GDP)}

United States is incomparable to Nigeria in terms of land mass. Nigeria has 923,768 Kilometres Squares while the United States is 9,857,306 kilometres square. This means United States is 10 times the size of Nigeria. That technically means Nigeria is easier to manage and developed compare to USA. The population of United States stands at 319,288,392 with a growth rate of $0.77 \%$ as at July 2013 while Nigeria has the population of $177,155,754$ with a growth rate of $2.47 \%$ (CIA World factbook November 2014). Despite the fact that the population of the United States is far higher than that of Nigeria the population growth rate of Nigeria is 
3 times more than that of United States. The figures in (Table 1) show that Nigeria both in terms of Land Mass and Population is less than that of US but has a growth rate of higher than that US. In other word they are two different environments when compare demographically. The United States has a GDP of $\$ 16,720,000,000,000$ and ranked number one in the world as of 2013 , while Nigeria has a GDP of $\$ 478,500,000,000$ ranked number $31^{\text {st }}$ in the world in 2013 according to the estimation of the CIA world facts book.

\section{Unemployment, Gross Domestic Product per Capita (GDP/Capita) and Crude Oil Production and Proven} Reserves.

The CIA world facts book rated US as number $79^{\text {th }}$ in 2013 with $7.30 \%$ unemployment rate while Nigeria was ranked at number $172^{\text {nd }}$ in 2011 with $23.90(\%)$ rate of unemployment. The statistical estimations above are clear about the fact that the economy of the United States is far much better than that of Nigeria despite their closeness in the amount of oil and gas reserves (see table: 1). The purchasing power as it is called per a Nigerian head is very low, been ranked as number $179^{\text {th }}$ and unemployment rate of $23.90 \%$ ranked at $172^{\text {nd }}$ among nations. The result here shows a great different of the two environments in terms of economics despite the possession of huge crude oil by Nigeria. The estimate in 2012 by the CIA world facts book place US at number $13^{\text {th }}$ in ranking in terms of GDP/capita with $\$ 51,700$ while that of Nigeria as of 2013 ranked at number $179^{\text {th }}$ with GDP/capita of $\$ 2,700$.

According to the CIA fact book, the production capacity Nigeria is $2,524,000$ (bbl/day) ranked as number $12^{\text {th }}$ while US is ranked $2^{\text {nd }}$ but in term of crude oil reserved, the report shows that Niger has a reserve of $37,200,000,000(\mathrm{bbl})$ and ranked number $10^{\text {th }}$ while US was ranked number $13^{\text {th }}$ with a reserve of $20,680,000,000$ (bbl) in 2013.

\section{Proven Natural Gas Reserves/production, ease of doing business and Oil Exports.}

Nigeria in 2013 was ranked $9^{\text {th }}$ with a natural gas reserve of 5,153,000,000,000 (cu m) while the US was ranked number $5^{\text {th }}$ in 2012 with a reserve estimate of $9,459,000,000,000$ (cu m). In production estimate US was ranked as $1^{\text {st }}$ while Nigeria was ranked $29^{\text {th }}$. Considering Hydrocarbon Reserves the result shows that Nigeria is wealthier than the US, as can be seen in the data on reserve estimate of natural gas in (table 4.1). Perhaps US have more reserve than Nigeria but when the reserve is equated with the population, Nigeria has more of the commodity. In terms of oil export Nigeria is exporting oil far ahead of US.

The ease of doing businesses in the United States is far more encouraging than that of Nigeria as stated by the World Bank and IFC (2012) ease of doing business index rating of about 185 countries, the US ranked number $7^{\text {th }}$ while Nigeria was ranked as $170^{\text {th }}$ by the same report. A comparison between Nigeria and US suggests that Nigeria is not faring well in terms of human development despite the fact that it has more hydrocarbon reserves and exports more quantity of oil than US. The inability of Nigeria to do well in terms of GDP per capita and in human development which are based on the reports conducted by the Transparency International and the World Bank. The finding showed what is refers as the 'Dutch Disease' in Nigeria where corruption in government and private sector has continued to increase poverty and hinder any meaningful economic development. Even the NNPC operates illegal foreign account, says Senate committee (Premium Times 2014). Explaining the term 'Dutch Disease' Soludo (1998) suggest that it is an economic problem caused largely by natural-resource endowment that often impedes investments and growth. Looking at the report Nigeria was ranked number $6^{\text {th }}$ in terms of oil export with export capacity of 2,051,000 (bbl/day) while US were ranked $47^{\text {th }}$ with capacity of 43,800 (bbl/day) in the year 2009, which mean more revenue to Nigeria.

\section{Installed Electricity Capacity/Generation, Corruption Perception Index and Corruption Perception Index.}

Considering installed energy generation capacity, the CIA fact book ranked Nigeria as number $73^{\text {rd }}$ while US was $12^{\text {th }}$ with capacities of 5,900,000(KW) and 1,039,000,000 (KW) respectively while in terms of electricity production they are ranked $69^{\text {th }}$ and $2^{\text {nd }}$ with capacities of $20,380,000,000(\mathrm{KwH})$ and $3,886,000,000,000(\mathrm{KwH})$ in 2010.

Nigeria was rated by the Transparency International's corruption perception index rating 2013 as number $144^{\text {th }}$ out of 177 countries while US was rated $19^{\text {th }}$ in same year by the same organisation with a score of 73 and 25 respectively. Human Development Index According to the UNDP (2014) human development index rating, Nigeria was rated as number $152^{\text {nd }}$ and US as $5^{\text {th }}$ in terms of human development. 
Table: 1 Demographic and Socio-Economic Indices of USA and Nigeria

\begin{tabular}{|c|c|c|c|c|c|}
\hline $\mathrm{S} / \mathrm{N}_{0}$ & Description/Item & United States & Ranking/Date & Nigeria & Ranking/Date \\
\hline 1 & Land Mass & $9,826,675(\mathrm{SQ} \mathrm{Km})$ & $3^{\text {rd }}$ & 923,768 (SQ Km) & $32^{\text {nd }}$ \\
\hline 2 & Populatiossn & $319,288,392$ & $3^{\text {rd }}(\mathrm{July}, 2013)$ & $177,155,754$ & $7^{\text {th }}($ July, 2013) \\
\hline 3 & Population Growth Rate & $0.77 \%$ & 143rd (2014 estimate) & $2.47 \%$ & $33^{3 d}$ (2014 estimate) \\
\hline 4 & Unemployment rate & $7.30(\%)$ & $79^{\text {th }}(2013)$ & $23.90(\%)$ & $172^{\text {nd }}(2011)$ \\
\hline 5 & GDP per Capita & $\$ 51,700(2012)$ & $13^{\mathrm{th}}(2014)$ & $\$ 2,700(2013)$ & $179^{\text {th }}(2014)$ \\
\hline 6 & Gross Domestic Product (GDP) & $\$ 16,720,000,000,000$ & $1^{\text {st }}(2013)$ & $\$ 478,500,000,000$ & $31^{\text {st }}(2013)$ \\
\hline 7 & Installed Electricity Generation Capacity & $1,039,000,000(\mathrm{KW})$ & $2^{\text {nd }}(2010)$ & $5,900,000(\mathrm{KW})$ & $73^{\text {rd }}(2010)$ \\
\hline 8 & Electricity Production & $3,886,000,000,000(\mathrm{KwH})$ & $2^{\text {nd }}(2010)$ & $20,380,000,000(\mathrm{KwH})$ & $69^{\text {th }}(2010)$ \\
\hline 9 & Crude oil Production & $11,110,000$ (bbl/day) & $2^{\text {nd }}(2012)$ & $2,524,000$ (bbl/day) & $12^{\text {th }}(2012)$ \\
\hline 10 & Proven Reserves & $20,680,000,000(\mathrm{bbl})$ & $13^{\text {th }}(2013)$ & $37,200,000,000(\mathrm{bbl})$ & $10^{\text {th }}(2013)$ \\
\hline 11 & Oil Exports & 43,800 (bbl/day) & $47^{\text {th }}(2009)$ & $2,051,000$ (bbl/day) & $6^{\text {th }}(2009)$ \\
\hline 12 & Natural Gas Production & $681,400,000,000$ (cu m) & $1^{\mathrm{st}}(2012)$ & $31,360,000,000(\mathrm{cu} \mathrm{m})$ & $29^{\mathrm{h}}(2011)$ \\
\hline 13 & Natural Gas Reserves & $9,459,000,000,000$ (cu m) & $5^{\text {th }}(1 \operatorname{Jan} 2012)$ & $5,153,000,000,000$ (cum) & $g^{\text {th }}(2013)$ \\
\hline 14 & Carbon Emissions & $5,491,000,000$ (MT) & $2^{\text {nd }}(2011)$ & $75,960,000(\mathrm{MT})$ & $46^{\text {th }}(2011)$ \\
\hline 15 & Ease of Doing Business Index & & 7th (2014) & & $170^{\text {th }}(2014)$ \\
\hline 16 & Human Development Index & 0.914 & $5^{\text {th }}(2014)$ & 0.504 & $152^{\text {nd }}(2014)$ \\
\hline 17 & Comuption Perception Index & Score 73 & 19th (2013) & Score 25 & 144th (2013) \\
\hline
\end{tabular}

\section{Content Analysis Of Royal Dutch Shell's Sustainability Report}

The Royal Dutch Shell sustainability report is a Global Reporting Initiative (GRI) of self-disclosure. It is a kind of wide-ranging report comprising references to all operations carried out by Shell including those in Nigeria and the United States. The report features in line with procedures developed by the International Petroleum Industry Environmental Conservation Association (IPIECA), American Petroleum Institute (API) and International Association of Oil and Gas Producers (IAOGP) (Shell 2012).

\section{Content of Sustainability Report}

The content of the sustainability report of Royal Dutch Shell was examined and the number of times the collected and organized indicators were intended to guide the oil industries in addressing the problem of indigenous people and communities as advocated by IPIECA. The collected indicators are not compulsory guidelines for companies but were still adopted in this research for purpose of information and referencing (IPIECA 2012).

Table: 2 Content Analysis of Shells Sustainability Report for Mention of Indicators

\begin{tabular}{|l|l|l|l|}
\hline S/No & Explanation of Indicators & Number of Mention & Remarks \\
\hline $\mathbf{1 .}$ & Indigenous People & 1 & Indigenous people received one mention \\
\hline $\mathbf{2 .}$ & Managing Potential Impacts & 0 & \\
\hline $\mathbf{3 .}$ & Remediation of Impacts & 4 & Remediation received 4 mentions \\
\hline $\mathbf{4 .}$ & Human Rights & 19 & Human Right received 19 mentions \\
\hline $\mathbf{5 .}$ & Corruption Prevention & 5 & Corruption received 5 mentions \\
\hline $\mathbf{6 .}$ & Transparent Business Practice & 5 & Transparency received 5 mentions \\
\hline $\mathbf{7 .}$ & Legal Compliance & 1 & It was mention once \\
\hline $\mathbf{8 .}$ & Protecting the Environment & 0 & \\
\hline $\mathbf{9 .}$ & Social License to Operate & 0 & \\
\hline $\mathbf{1 0 .}$ & Access to Land & 0 & \\
\hline $\mathbf{1 1}$. & Access to International Financing & 0 & Society received 8 mentions \\
\hline $\mathbf{1 2 .}$ & Societal Expectations & 8 & \\
\hline $\mathbf{1 3 .}$ & Infrastructural Development & 0 & \\
\hline
\end{tabular}

\section{Major Subjects of the Report and the CSR Committee}

Carbon dioxide emission, Employees, Environment, Energy feature, Safety, Spill, Society, Standards and Technology were the major subject used by Shell in its 2012 sustainability report. Shell used its own criteria based on a five level selection procedures, which concentrates on the environmental and social challenges. According to them, these indicators are the most important to their stakeholders (Society or Community) for Social Investment Disclosure (SID). As mentioned by Shell, its stakeholders include local communities, cohorts, government, non-governmental organisation, investors, media, academics, customers, shareholders, contractors and suppliers (Shell Sustainability Report 2012 p 42). This shows the level of Shell's recognition to the stakeholder's theory of CSR. The existence of Corporate Social Responsibility (CSR) Committee was the only referral made by Shell in its 2012 SID. However, it mentions social voluntary contribution to the society as Social Investment (SI). The CSR policy of Shell reflects or agrees with the categorization of CSR by Elbert and Parket (1973). 
Results from the SID of Shell shows that it has put a number of social investments both in Nigeria and United States. In the USA, Shell social investments search for and support programs that are vital to the community as their activities in the Gulf is also vital to the community. Shell has in place, the following intervention schemes. According to Shell sustainability report (2012): "Deep-water projects are vital to US Gulf Coast communities, providing jobs and helping to sustain a way of life. As we develop our Mars B deep-water platform, Shell is investing in a range of projects to help protect coastal communities." Shell pledged to community and environmental projects which include "(i) $\$ 5$ million restoration of wetlands and coastlines damaged by hurricanes. (ii) Shell is providing $\$ 1$ million to support a project that will almost double the size of Pelican Island, Louisiana, an important habitat for nesting wading birds that is threatened by coastal erosion. (iii) Shell is providing $\$ 500,000$ to fund The Nature Conservancy's restoration efforts on Shamrock Island in Corpus Christi Bay, Texas, another vital nesting habitat for up to 21 species of birds. (iv) Shell also donated $\$ 500,000$ to the Greater Lafourche Port Commission to restore and maintain a $1.6 \mathrm{~km}$ section of storm-damaged beach in Louisiana.(vi) Shell is working to increase understanding of the local environment by supporting a scientific documentary by the Gulf of Mexico Foundation, a non-profit conservation organisation.(v) Shell involved 90 children from three schools in a community project to clean debris from $61 \mathrm{~km}$ of coastline on Matagorda Bay in Texas. (vi) They also engage some students in the production of an educational video on the project.(vii) Shell donation of $\$ 1$ million is helping to fund the construction of the Bayou Country Children's Museum in Thibodaux, Louisiana, which started in 2012 (Shell Sustainability Report 2012: 8)". As stated in the Shell's (2012: 22) SID, its social investments in Nigeria include, "(i) Shell contributed \$68.2 million USD, it also paid its own share of contribution of $\$ 178.3$ million joint venture to the NDDC in 2012.(ii) Provided scholarships worth $\$ 5.3$ million USD as educational support to communities.(iii) The company paid the Federal Government of Nigeria for a period of five years Royalty and Taxes of up to of $\$ 40$ billion USD. (iv) Shell's Social Investment (SI) voluntary contribution aiming at addressing socio-economic challenges in the Niger Delta worth $\$ 31.4$ billion USD. (v) 4,000/30,000: estimated direct and indirect jobs created by SPDC and SNEP Co in Nigeria (vi) $\$ 103.2$ million 2012 contribution from SPDC and SNEPC to community development projects (Shell share \$31.4 million)". From Shell's SID of 2012, it appears that the social investment (SI) or CSR programmes set by Shell in the United States and Nigeria are different. The difference is assumed to be as a result of the demographic and economic variation of the two countries as observed in Table 1.

\section{ADEQUACY OF SOCIAL INVESTMENTS (SI)}

Without the acquisition and continuing community backing (Social licence to operate), a company will not find it easy to effectively function (Yates and Horvath, 2013). Community and Indigenous people have strong expectation from the company that operates on their land, in terms of respecting their rights, offering them with prospects and moderating any potential effect their activities may have on the environment (IPIECA, 2012). Procedures adapted by oil companies to achieved and sustain community backing include social reserves (Yates and Horvath 2013). In other word, there is close connection between social investment and achieving and sustaining community backing. Therefore, it is important and necessary for a company to assess the success and adequacy of their social investment in addition to SID. However, this measurement is not that simple because companies hardly set baseline against which the adequacy or success of SI are measured when designing SI projects rather they measure their SI success and adequacy in term of outputs and not outcomes (IPIECA 2012). It is imperative for oil firms to measure their SI against key performance indicators (KPI) set by IPIECA in 2008. Nevertheless, for quality KPI, more than single indicators are essential to measure local backing or lack of it by oil firms (IPIECA 2008). The KPI developed by IPIECA (2008) were used to measure the adequacy of Shell's CSR/SI using information (from secondary source) and reportage of the company's operation in Nigeria. The lacks of good will social performance indicators developed by IPIECA (2008) were used and the findings were shown in the table below.

Table: 3 Showing "Lack of Goodwill Indicators", for the purpose of this work, the following is adapted. Yes - Means such tendency exists while No - such tendency does not exist or may exist but no documented facts available to the researcher.

\begin{tabular}{|c|c|c|c|}
\hline $\mathrm{S} / \mathrm{NO}$ & $\begin{array}{l}\text { Stakeholder } \\
\text { relationship }\end{array}$ & No local goodwill or support indicators (source: IPIECA 2008 p 42) & $\begin{array}{l}\text { Remarks } \\
(\text { Yes/No) }\end{array}$ \\
\hline \multirow[t]{11}{*}{1} & \multirow{11}{*}{$\begin{array}{l}\text { Company and } \\
\text { Community }\end{array}$} & Rising trends in theft ((no reporting and company is seen as the target) & Yes \\
\hline & & Work stoppages & Yes \\
\hline & & - Increase demand and hostile tone of the communities & Yes \\
\hline & & No leniency when accidents happen & Yes \\
\hline & & Bad press & Yes \\
\hline & & - $\quad$ Increasing crime in the area of operations & Yes \\
\hline & & - Increasing conflict between or within communities & Yes \\
\hline & & - $\quad$ Kidnapping or targeted assaults towards companies & Yes \\
\hline & & - $\quad$ Sabotage & Yes \\
\hline & & Increased reliance on police and army & Yes \\
\hline & & Communities say the company is stealing resources & Yes \\
\hline \multirow[t]{5}{*}{2} & \multirow[t]{5}{*}{$\begin{array}{l}\text { Corporation and } \\
\text { Government }\end{array}$} & $\begin{array}{l}\text { - Government encourages communities to demand (and expect) provisions of } \\
\text { social services from the company }\end{array}$ & No \\
\hline & & - $\quad$ State security forces are involved in sabotage activities against the company & Yes \\
\hline & & State security forces are a risk to corporate and staff assets & No \\
\hline & & Security forces attached to company commit human rights abuses & No \\
\hline & & Government revenues are used for warfare and violence against the citizenry & No \\
\hline \multirow[t]{2}{*}{3} & \multirow{2}{*}{$\begin{array}{l}\text { Corporation and } \\
\text { Critics }\end{array}$} & NGO encourage community demonstrations & No \\
\hline & & NGO advocacy campaign against the company & Yes \\
\hline
\end{tabular}




\begin{tabular}{|l|cll|l|}
\hline \multirow{4}{*}{} & $\bullet$ & Divestment campaign against company/consumer boycotts & No \\
\cline { 2 - 4 } & $\bullet$ & Shareholder activism critical of company's actions & No \\
\cline { 2 - 5 } & $\bullet$ & Websites against company & Yes \\
\hline & $\bullet$ & NGOs and lawyers actively seeking witnesses for court cases & Yes \\
\cline { 2 - 5 } & $\bullet$ & Litigations. & Yes \\
\hline
\end{tabular}

Looking at Table: 3, Twenty-four KPI are found, out of which sixteen indicators are confirming lack of goodwill. Based on this statistic, it will be accurate to say that the SI (CSR) of Royal Dutch Shell Company in Nigeria is inadequate. To buttress this findings the following points are highlighted;

- In an article in the Guardian newspaper (2013) cited in Olaniyan (2012) John Vidal stated that Shell is presently is in litigation in which Ogoni community in Niger Delta of Nigeria rejected a 'derisory offer' amounting to thirty million British Pounds as payment to compensate for oil spills. Hence, it is a sign that the community no longer has leniency for the company (Table: 3 ).

- Christian Purefoy of CNN reports on the illegal refining of crude oil in Niger Delta says, government and community blame each other for the shattered life oil spillage and pollution of the environment. An illegal oil refinery operating in Niger Delta Area of Nigeria documented by CNN news With the Help of Shell Petroleum Company (CNN 2014).

- An article in Observer of $6^{\text {th }}$ of October, 2013, John Vidal reported that crude theft and related crime has become so alarming, where by sabotage of oil exploration work, destructions of oil pipelines, crude oil theft and illegal mining have become rampant. Crude oil theft is found to be supported by security personals of Nigeria, which resulted to the dismissal of two Rear Admirals of the Nigerian Navy for involvement in the disappearance of a crude oil tanker detained for conveying stolen crude oil.

- Royal Dutch Shell in its annual report (2012: 22), reported that from the year 2008 to 2012 sabotage and criminal activities resulted to 76\% of oil that disappear from SPDC facilities (Shell's annual report 2012). In 2012, the Nigerian government setup the Hydrocarbon Pollution Restoration Project (HYPREP) to monitor and organize the activities required to implement the commendations of United Nations Environment Programme (UNEP) report on oil pollution in Ogoni land. This is an area of the Niger Delta from which SPDC pulled out in 1993 following many years of attacks on staff and facilities (UN Environmental programme report 2012).

- An NGO known as Socio-Economic Rights and Accountability Projects sued the International Oil Companies in Nigeria (Shell inclusive) and the Federal Government on behalf of the people of Niger Delta (ECOWAS COURT 2012). In this case, the NGO and the lawyers required for witnesses from the community, which are affected and engaged activism against Shell which is an indicator of lack of goodwill.

- Several stoppage of work by Shell has been reported in the Niger Delta region of Nigeria due to incessant kidnap of staff, violence, and clash with communities and armed militancy. There are also cases of confrontation between securities guarding Shell's facilities and the militant in the region. These are reported in CIA Fact book (2012); Shell annual report (2012: 22).

- At various times, Shell has also received bad press on cases of environmental pollution and crime against humanity especially when a human right activist in the region Ken SaroWiwa was executed. They are also accused of ripping off the inhabitants of the region from full benefit and value for their resources.

\section{Summary and Conclusion}

The findings of this research work revealed that Shell has not specifically pronounce a universal SI (CSR) strategy, but has in place numerous Social Investment (SI) structures for Nigeria and the United States. The social investment (SI) programmes Shell has in place in Nigeria (case study) was tested using the "lack of goodwill" KPI developed by IPIECA 2008 and was found to be inadequate. However, a different demographic environment permits different social investment. The consideration can be attributed to the socio cultural backgrounds of the communities and the indigenous people. The inadequacy of the SI structure in Nigeria can be as a result of the following observed factors: It appears that Shell measured their social investment in Nigeria in terms of output and not outcome as well as the high rate of corruption in the Nigerian oil and gas sector.

\section{References}

[1] Amadi, L. 2013, "Climate change, peasantry and rural food production decline in the Niger Delta flood disaster", Journal of Agricultural and Crop Research, vol. 1, no. 6, pp. 94-103.

[2] Bowen, H. R., \& Johnson, F. E. (1953). Social responsibility of the businessman. Harper

[3] Carroll, A.B. 1999, "Corporate social responsibility evolution of a definitional construct", Business \& Society, vol. 38, no. 3, pp. 268-295.

[4] Central Intelligence Agency (2013) CIA Fact Book. [Online] Available from<http://www.cia.gov/library/publications/the -worldfactbook/geog/ni.html> [30 September 2014] 
[5] Christian Purefoy of CNN (2014) Death and Oil in Niger Delta's Illegal Refineries.[Online] Availablefrom<https://www.facebook.com/video.php?v=421126241975\&set=vb.119586 108487\&type=2\&theate>[27 October 2014]. Central Intelligence Agency (2013) CIA Fact Book. [Online] Available from<http://www.cia.gov/library/publications/the world-factbook/geog/ni.html> [30 September 2014]

[6] Ease of Doing Business Index (2012) Ease of doing business index: most business-friendly regulations [Online] available from <http://data.worldbank.org/indicator/IC.BUS.EASE.XQ>[26 November 2014].

[7] Economic Community of West African States (2012)ECOWAS Community Court of Justice Focuses on Effective Implementation.[Online] available from<http://hrbrief.org/2012/11/ecowas-community-court-of-justice-focuses-on-effectiveimplementation/> [01 November 2014].

[8] Eilbert, H. and Parket, I. R.(1973) 'The Current Status of Corporate Social Responsibility’. Business Horizon, Volume 16, 5-14

[9] Gonzalez-Padron, T. L. (2008). Turning Corporate Social Responsibility Into Opportunity: A Study of Stakeholder Orientation and Marketing. ProQuest.

[10] Ikelegbe, A. (2005). The economy of conflict in the oil rich Niger Delta region of Nigeria. Nordic Journal of African Studies, 14(2), 208-234.

[11] International Finance Corporation/World bank, 2013.Ease of Doing Business Index. [Online] Available from $<$ http://www.doingbusiness.org/ranking > [26 November 2014].

[12] International Petroleum Industry Environment Conservation Association (IPIECA) (2012) 'Preventing Corruption: Promoting TransparentBusinessPractices.[Online]availablefrom<http://www.ipieca.org/library? $\mathrm{x}=0 \& \mathrm{y}=0 \& \mathrm{tid} \% 5 \mathrm{~B} \% 5 \mathrm{D}=11 \&$ date_filter\%5Bva lue $\% 5 \mathrm{D} \% 5$ Byear\% $>$ [30 October 2014].

[13] International Petroleum Industry Environment Conservation Association (IPIECA) (2008) Guide to Successful Social Investment fortheOilandGasIndustry.[Online]availablefrom<http://www.ipieca.org/library? $\mathrm{x}=0 \& \mathrm{y}=0 \&$ tid $\% 5 \mathrm{~B} \% 5 \mathrm{D}=11 \&$ date_filter\%5Bvalue $\%$ 5D\%5Byear\% 5> [30 October 2014]

[14] Niger Delta Partnership Initiative (NDPI)(2013)Annual Report:Empowering Economic Entrepreneurs and Peace Advocates. [Online] available from <http://ndpifoundation.org/> [26 October 2014].

[15] Plaza, O. S., \& Deisler Jr, P. F. Shell Oil Company.nd

[16] Shell Annual Report (2012) Shell Global Homepage. [Online] Available from<http://www.shell.com/> [27 October 2014].

[17] Stainer, L. (2006). Performance management and corporate social responsibility: the strategic connection. Strategic Change, 15(5), 253-264.

[18] SustainabilityReport (2012) Royal Dutch Shell plc Sustainability Report. [Online] Available from<http://reports.shell.com/sustainabilityreport/2012/servicepages/welcome.html> [15 October 2014 $]$

[19] Transparency International (2013) Corruption Perception Index. [Online] available from<http://www.transparency.org/cpi2011/results> [24 November 2014].

[20] Tribal Energy and Environmental Information Clearinghouse (n.d) Oil and Gas Resources in the United States. [Online] available from <http://teeic.indianaffairs.gov/er/oilgas/restech/dist/index.htm> [15 October 2014]

[21] Ukiwo, U. (2009). Causes and cures of oil-related Niger delta conflicts

[22] United Nations Development Program (2013) Human Development Report. [Online] available from <http://www.hdr.undp.or/en/statistics/hdi/> [28 October 2014].

[23] United State Energy Information Agency (2012) Annual Energy Review.[Online] available from $<$ http://www.eia.gov/totalenergy/data/annual/> [30 October 2014]

[24] Vidal, J.(2013) 'Niger Delta Oil Spill Victims Reject 'Derisory' Shell Compensation Offer'. The Guardian, 13 September2013

[25] Vidal, J.(2013)' '1 billion pounds a month: the spiralling cost of oil theft in Nigeria'. The Guardian/ The Observer, 06 October 2013

[26] Yates, B. F., \& Horvath, C. (2013). Social license to operate: How to get it, and how to keep it. Pacific Energy Summit Working Papers. 